\title{
DIFFERENCE DERIVED FROM WEIGHTED HÖLDER'S INEQUALITY
}

\author{
SAICHI IZUmino, Josip PeČArić AND Masaru TOMinaga
}

Abstract. We give the maximum of the difference

$$
D_{p}(a, b ; w):=\left(\sum_{k=1}^{n} w_{k} a_{k}^{p}\right)^{\frac{1}{p}}\left(\sum_{k=1}^{n} w_{k} b_{k}^{q}\right)^{\frac{1}{q}}-\sum_{k=1}^{n} w_{k} a_{k} b_{k}
$$

derived from a weighted Hölder's inequality for $p, q>1, p^{-1}+q^{-1}=1$ and for positive $n$-tuples $a:=\left(a_{1}, \ldots, a_{n}\right), b:=\left(b_{1}, \ldots, b_{n}\right)$ and a weight $w:=\left(w_{1}, \ldots, w_{n}\right)$ under certain conditions. The discussion in this note is simpler than our previous ones. It comes from the arrangement of a given weight and a linearization of $D_{p}(a, b ; w)$ via Young's inequality. As a consequence, we give $a, b$ and $w$ which attain the maximum.

Mathematics subject classification (2000): $26 \mathrm{D} 15$.

Key words and phrases: Hölder's inequality, convex function, Ozeki’s inequality.

\section{REFERENCES}

[1] S. IZUMINO, Ozeki's method on Hölder's inequality, Math. Japon., 50, (1999), 41-55.

[2] S. IzUmino, H. Mori AND Y. SEO, On Ozeki's inequality, J. Inequal. Appl., 2, (1998), 235-253.

[3] S. Izumino, M. TominaGA, Estimations in Hölder's type inequalities, Math. Inequal. \& Appl., 4, 2 (2001), 163-187.

[4] D. Mitrinović, J. E. PEČArić And A. M. FinK, Classical and New Inequalities in Analysis, Kluwer Academic Publishers, Boston, London 1993.

[5] N. OZEKI, On the estimation of the inequalities by the maximum, or minimum values (in Japanese), J. College Arts Sci, Chiba Univ., 5, (1968), 199-203.

[6] E. ZEIDler, Applied Functional Analysis; Main Principles and Their Applications, Applied Mathematical Sciences 109, Springer-Verlag, New York, 1995. 